\title{
A influência do jejum no desempenho do exercício de força e suas consequências no begeamento do tecido adiposo branco.
}

\section{Guilherme F. Peruca*, Alexandre B. Gallo, Kellen C. C. Rodrigues, Rodrigo M. Pereira, Diego Gomes de Melo e Leandro Pereira de Moura.}

\section{Resumo}

É de suma importância para a ciência estudar métodos eficazes para combater a obesidade. Deste modo, este projeto visa analisar a combinação de duas estratégias não-farmacológicas, o jejum e o exercício de força, e mensurar o possível efeito sinérgico entre elas no combate à obesidade.

\section{Palavras-chave:}

Jejum, Exercício de força, Begeamento do TAB.

\section{Introdução}

É comprovado que a prática de exercício físico (1) e de jejum (2) causam modificações morfofisiológicas no tecido adiposo branco (TAB) como o aumento na concentração de mitocôndrias e no conteúdo de UCP-1, levando assim, ao begeamento desse tecido. Entretanto, ainda não se sabe se a combinação destas estratégias poderia potencializar tais efeitos. Diante disso, este projeto avaliou os efeitos agudos de três protocolos gradativos de jejum (4h, 8h e 16h) no desempenho do exercício de força e em marcadores do begeamento do TAB de camundongos C57BL/6J. Para isto, dados fisiológicos e de expressão gênica foram coletados e analisados.

\section{Resultados e Discussão}

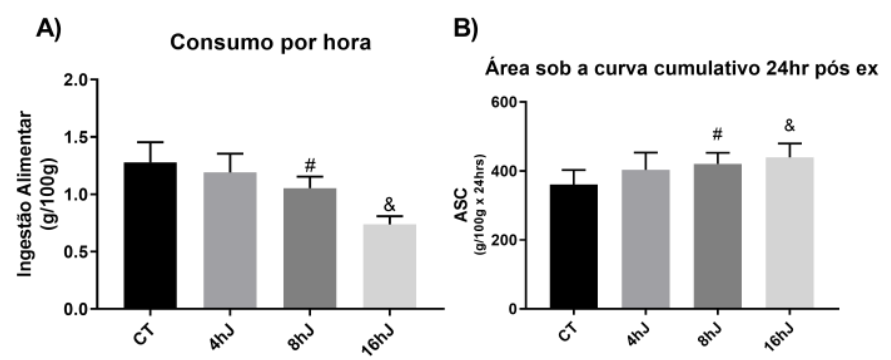

Figura 1. Dados do consumo.
A)

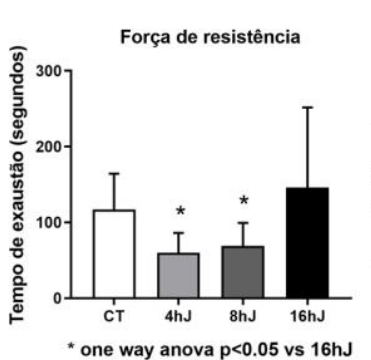

B)

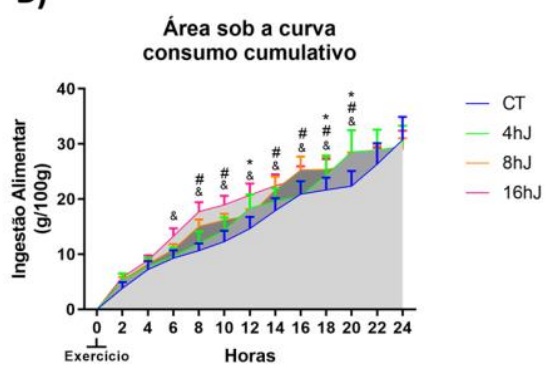

A)

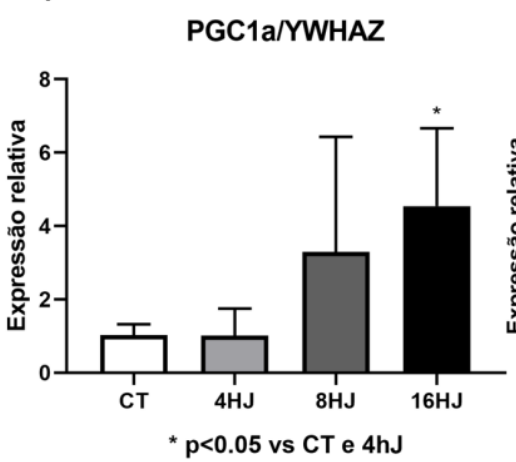

B)

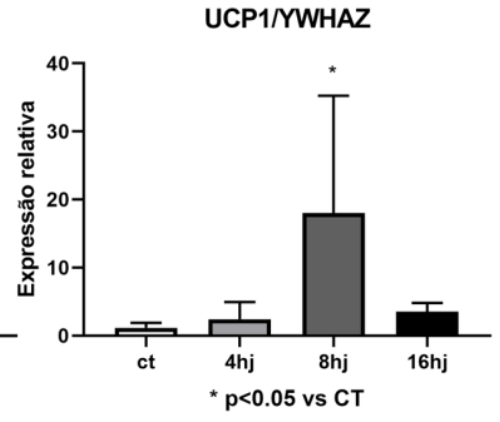

Figura 3. Dados de expressão de mRNA PGC1a subcutâneo (A) e UCP1 (B) subcutâneo.

\section{Conclusões}

Com os resultados fisiológicos encontrados, foi possível concluir que, o consumo por hora do grupo $16 \mathrm{HJ}$ foi inferior ao restante dos grupos, entretanto, o grupo se alimentou mais após o exercício, como mostra a área sob a curva da ingestão. Além disso, em relação ao teste de força de resistência, o grupo $16 \mathrm{HJ}$ teve um tempo maior do que os grupos $4 \mathrm{HJ}$ e $8 \mathrm{HJ}$. Mediante a isto, é possível averiguar que os grupos de jejum não têm diferença significante entre o CT. Assim, revelando que a prática do jejum não existe redução da performance, porém há uma diferença entre os tempos do jejum, sendo o $16 \mathrm{HJ}$ mais eficaz do que o $4 \mathrm{HJ}$ e $8 \mathrm{HJ}$.

As análises de mRNA revelaram que os tempos de jejum de $8 \mathrm{~h}$ e $16 \mathrm{~h}$ poderiam ser melhor conciliados com o exercício de força para estimular o begeamento do TAB, uma vez que eles aumentaram os níveis de UCP1 e PGC1a, respectivamente.

\section{Agradecimentos \\ FCA}

- JaPESP
Figura 2. Dados do teste de resistência $(A)$ e área sob a curva de dados de ingestão (B).
1. Balducci S, Sacchetti M, Haxhi J, Orlando G, D’Errico V, Fallucca $\mathrm{S}$, et al. Physical exercise as therapy for type 2 diabetes mellitus. Diabetes Metab Res Rev. 2014 Mar 1. Available from: http://doi.wiley.com/10.1002/dmrr.2514

2. Li G, Xie C, Lu S, Nichols RG, Tian Y, Li L, et al. Intermittent Fasting Promotes White Adipose Browning and Decreases Obesity by Shaping the Gut Microbiota. Cell Metab. Available from: http://dx.doi.org/10.1016/j.cmet.2017.08.019 